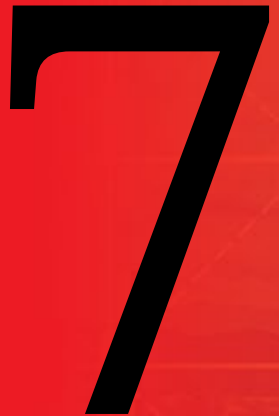

\title{
POLICING THE BORDERS:
}

Carolyn Cartier

\section{HONG KONG CONUNDRUMS}



The philospher and social theorist Michel Foucault was the first to conceptualise the effects of the state and state power as 'governmentality', which is expressed in Chinese as the 'art of control and governance' 治理 术. Chinese scholars of political theory are very familiar with this concept. Rather than treating state power as a uniform thing, agent or authority, 'governmentality' focuses on the use and implementation of state power and its effects. The Chinese state does not normally disclose governing strategies; they are revealed through the identification and analysis of their outcomes and impacts. Because the Constitution gives the Party-state the power to change the borders and definitions of subnational territories and govern them in new ways, the territorial contexts of governance are often especially significant. ${ }^{1}$

\section{Governing Borders}

On 11 March 2016, the Hong Kong Legislative Council 香港特別行政区立法 会 (LegCo) Finance Committee passed a bill that appeared to be a technical matter of railway funding, but which carried heavy ideological freight. What's more, it passed the bill while members of the Council's pan-democratic camp 泛民主派 (which refers to a political alignment in Hong Kong

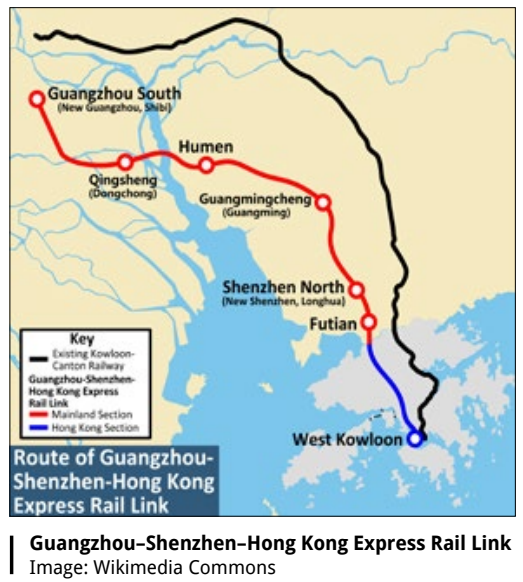

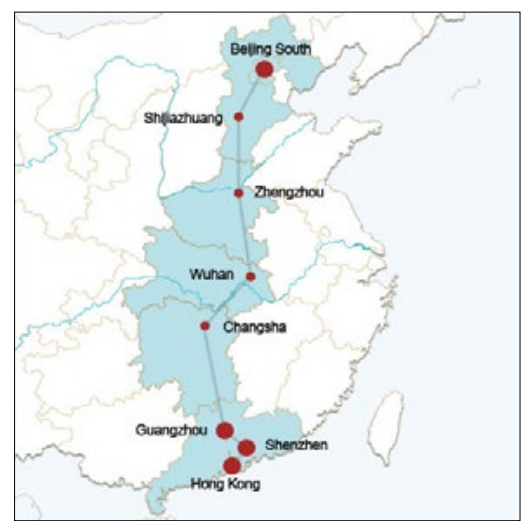

Chinese national high-speed rail system Image: chineseeye.com 


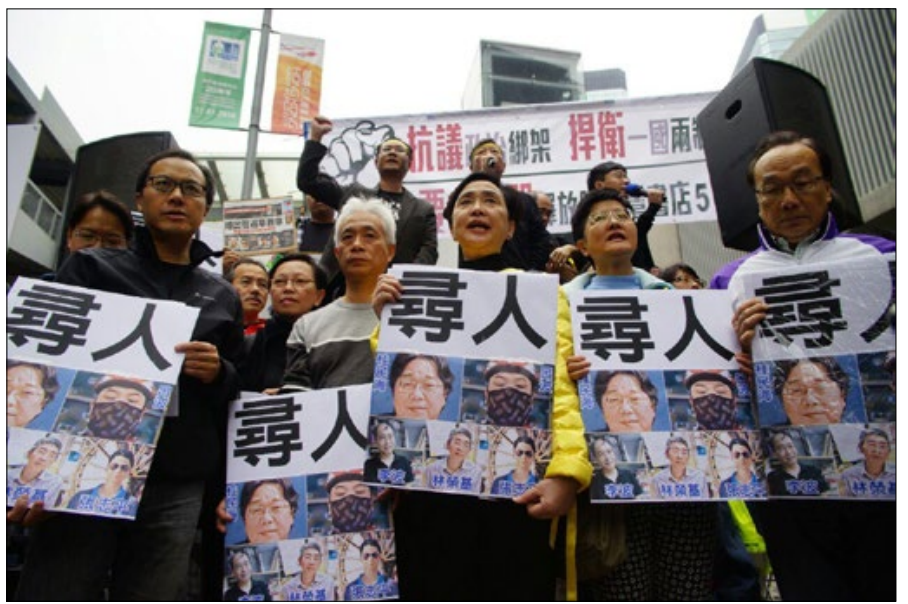

January 2016: Pan-democrats protesting about the missing booksellers Source: Inmediahk, Flickr

that supports increased democracy, including the values of the rule of law, human rights, civil liberties, and social justice), who would have opposed it, were out of their seats. ${ }^{2}$ This ignited a storm of controversy.

The vote was to approve an additional HK\$19 billion (US $\$ 2.45$ billion) funding package for the Guangzhou-Shenzhen-Hong Kong Express Rail Link 广深港高速铁路 (XRL) - a fourteen-minute, twenty-six kilometre rail link between West Kowloon and the Hong Kong-Shenzhen border. The Hong Kong XRL is the southernmost portion of the People's Republic's national high-speed rail system. In 2010, LegCo authorised funding for the Hong Kong government-owned Mass Transit Railway (MTR) to begin constructing the project. Nineteen billion dollars is a supplement to the original price tag of HK\$61 billion (US\$7.86 billion) — an additional expense of almost one-third of the original estimate. The link will be the most expensive rail line in the world per kilometre because it is a tunnel - a twenty-six kilometre tunnel through Hong Kong's New Territories and under the mainland China border. ${ }^{3}$

The link's lack of intermediate service within Hong Kong has compounded local concerns about its cost and engineering requirements. One out of five people in Hong Kong live in poverty, and the territory has one of the widest income gaps among developed economies. Protests against 


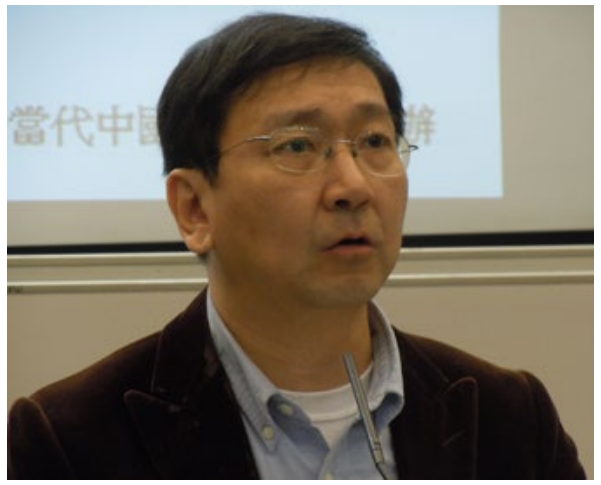

Johannes Chan Man-mun

Photo: zh.wikipedia.org the XRL concerned the Hong Kong government's prioritisation of expenditure (in planning jargon) of 'pre-demand infrastructure' over the people's welfare. Projections show that the majority of XRL riders will be from Guangdong province. As the Hong Kong Citizens' Media reported, 'If it is based on the user pays principle, why should it

not be funded by the Central Government [Beijing]?"4

The controversies around the XRL in 2016 weren't confined to governing cost and construction - there were political questions too. The plan calls for the 'co-location' 一地雨检 (literally 'one place-two inspections') of Hong Kong Special Administrative Region (SAR) and PRC immigration controls at the West Kowloon terminus. Co-location is a hot political issue because under 'One Country, Two Systems', 一国两制 the foundational policy basis of the Hong Kong SAR, only Hong Kong SAR institutions govern Hong Kong.

Eurostar passengers departing London for France complete French immigration procedures before boarding the train. Canadian airports have US immigration facilities for passengers flying to destinations in the United States. But these arrangements involve countries with complementary governing systems. Under the Basic Law of the Hong Kong SAR, Hong Kong maintains freedoms of speech, publication, and demonstration. These rights do not exist in mainland China, where public security organs have the power to detain citizens who express alternative views. These differences can make the border and border crossings a political issue - and Chinese border security already has a history of politicising immigration procedures in Hong Kong's neighbouring SAR of Macau. 
For example, in March 2009, Macau SAR immigration denied entry to Johannes Chan Man-mun 陳文敏 — the dean of the law faculty at the University of Hong Kong - who was en route to the University of Macau. This happened just days after the Macau SAR passed new national security legislation, which forbids, and sets out punishments for, national crimes of 'treason, secession, and subversion'. Chan had been a founding member of the Basic Law Article 23 Concern Group 《基本法》二十三条关注组, which had successfully lobbied against a similar law for Hong Kong. Many other Hong Kong politicians, lawmakers and journalists were denied entry to Macau from late 2008 through early 2009, and Macau immigration admitted there was a denial-of-entry list. ${ }^{5}$ The bans were undoubtedly a message of displeasure from Beijing at Hong Kong's refusal to pass its own national security law.

Incremental changes to territorial governance also lead to new negotiations with opportunities for expanding governing control. In December 2015, the Hong Kong Secretary of Justice, Rimsky Yuen Kwok-keung 袁國 強, said of the co-location issue: 'it was inevitable that mainland personnel must be allowed to enforce laws in the XRL West Kowloon Terminus' ${ }^{6}$ Because the Hong Kong government had yet to assess the legal basis of co-location, observers inferred that there had been an advance, secret agreement between the Hong Kong executive and the Chinese government.

Yet according to Article 18 of Hong Kong's Basic Law, China's national laws cannot be applied in Hong Kong except for those related to defence, diplomacy, and other matters that 'fall outside the autonomy of the Hong Kong SAR'. Only the Standing Committee of the National People's Congress can approve changes to this law. Whether mainland laws

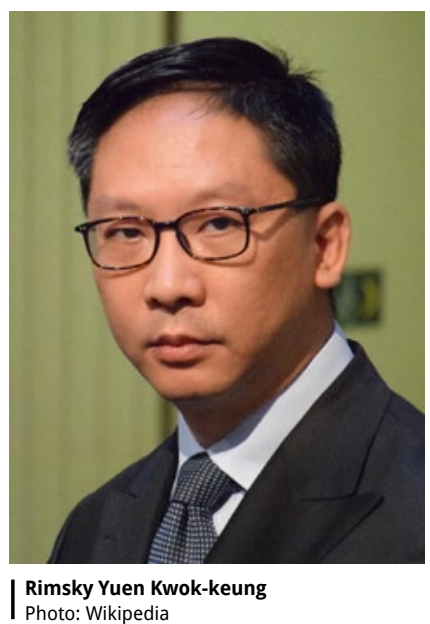




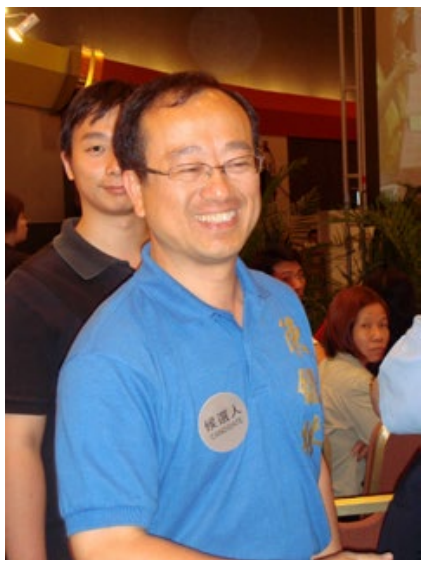

Chan Kam-lam

Photo: Wikipedia

concerning immigration, customs, and quarantine could fit into one of the three specified categories became another subject of negotiation. Legal experts contend that either Hong Kong or both Hong Kong and the mainland would need to enact separate laws to implement co-location. ${ }^{7}$ The pan-democrats and other concerned pro-democracy groups in the territory, meanwhile, view co-location as the thin end of a wedge of control.

In advance of the 11 March Finance Committee meeting, nineteen lawmakers of the pan-democratic camp filed 1,262 motions that questioned both the additional funding package and the co-location issue. But only thirty-six were tabled. Concerned with how the acting chair of the committee, Chan Kam-lam 陳鑑林, was handling the debate, some in the democratic coalition rushed to the chairman's table to try and remove his microphone. One sprayed Chan with ink, and soon it was chaos. Chan suddenly called the vote while most pan-democrat members were out of their seats. Pan-democrats consequently charged that the vote should be voided, and apologised to the Hong Kong people for not blocking the funding. ${ }^{8}$

\section{Governing Freedoms of Expression}

Concerns over the stability of the Hong Kong SAR as a territory under separate governance, with legally secure rights and freedoms, continued to rise in 2016 as a consequence of the ongoing saga of the detained Hong Kong booksellers. They had been involved in the production and distribution of tabloid-style accounts of the lives of China's national leaders, including the current Chinese Communist Party Chairman and President 
Xi Jinping. Estimates suggest that the publishing house Mighty Current 巨 流傳媒有限公司 accounted for one third to one half of the market for such books, which are banned in mainland China. Mighty Current's most recent bestseller was 2016: Collapse of the Communist Party of China 2016 中共崩 潰, and it planned to bring out a book called either Xi Jinping and His Lovers or Xi Jinping and His Six Women, with content including compromising political incidents. ${ }^{9}$ In mainland China, where such titles are known as 'wild histories' 野史, no such books can be legally published or sold.

Widely reported in the local and international media, the detentions raised questions about the unusual extension of non-transparent forms of governance and control over individuals' rights and protections from unwarranted search and seizure, as well as about freedoms of the press and publication in the Hong Kong SAR. Any potential for mainland security agents to detain Hong Kong citizens in Hong Kong and then to transport them to the mainland undermines the Basic Law and poses complex questions about territorial governance.

The case of the booksellers includes incidents of unexplained or extrajudicial transborder travel, and detention without warrant while crossing the border. Gui Minhai 桂敏海 — a naturalised Swedish citizen and owner of the Mighty Current publishing house — was living in Pattaya when he suddenly departed his home in October 2015 without warning and with unnamed 'visitors'. His whereabouts was unknown until January 2016, when he appeared on Chinese Central Television claiming that he had gone voluntarily to China. In December 2015, Lee Bo 李波, a British passport holder, apparently left Hong Kong while on an errand to the bookstore warehouse in Chai Wan; subsequent investigation showed no record of him passing through Hong Kong-Shenzhen immigration or any other checkpoint, and at the time he was not in possession of his Hong Kong identity

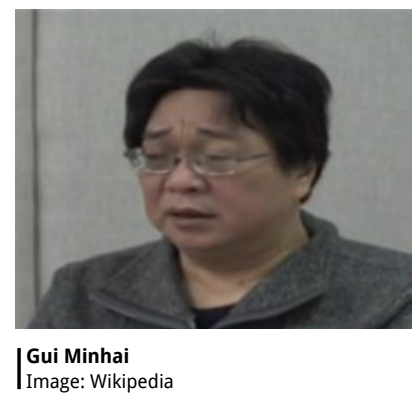




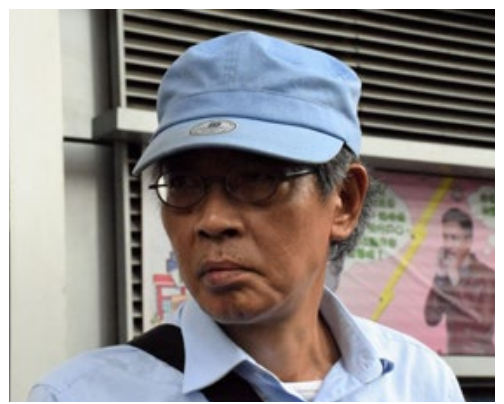

Lam Wing-kee

Image: zh.wikipedia.org card, used by SAR residents to cross the border. In February 2016, Lee Bo appeared on Hong Kong-based Phoenix Television, broadcasting from mainland China, in which he renounced his British citizenship and stated he had 'resorted to illegal immigration' in order to 'cooperate in a judicial investigation'. ${ }^{10}$ Neither Gui nor Lee, presumably under

pressure, would publically confirm exactly how they arrived in mainland China.

Three additional employees were detained in October 2015. Two were already in Guangdong province. The third, Lam Wing-kee 林榮基, the bookstore manager, was detained while crossing into the mainland at Hong Kong-Shenzhen immigration. After a period incommunicado in the mainland, the men made televised statements and signed documents attesting to 'voluntary' co-operation in an investigation into the transport and sale of 'banned books'.

In the first half of the year, and in the absence of information about the men, a range of speculative accounts emerged. For example, a pro-government LegCo politician, Regina Ip Lau Suk-yee 葉劉淑儀, made the puzzling statement that 'undocumented exit from Hong Kong does not constitute an offence' since there are 'many ways to enter the mainland without going through the proper immigration channels'. ${ }^{11}$ In an interview with Hong Kong's Commercial Radio, she stressed: 'there is no "permanent resident unauthorised exit and entry ordinance", there is none'. ${ }^{12}$ But according to this outlook, if there are many ways to enter and exit the mainland and undocumented exit does not constitute an offence, then people could 'randomly' cross the border. Ip's statement represents how a unitary state formation, without multiple parties and separation of powers, can engage in targeted decisions and idiosyncratic changes with unusual effects that require subsequent efforts to normalise them. 
Two days after being allowed to return to Hong Kong in June 2016, Lam Wing-kee openly recounted to the press how he had been detained at the border, handcuffed, hooded, and sent on a train to Ningbo, Zhejiang province. There, he said, he was incarcerated, interrogated, and pressed to sign agreements that stated he would not contact either legal counsel or his family. According to the terms of his release and 'bail', Lam would assist investigators by going back to Hong Kong to collect documentation on the bookstore's

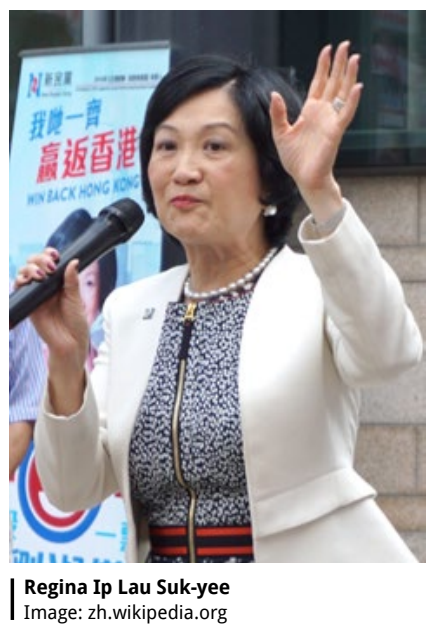
clients and return with it to the mainland. In his media statement, Lam stated 'I have no plan to go to the mainland again'. ${ }^{13}$ Lam's public statement 'exposed what many have suspected all along', said Mabel Au, director of Amnesty International Hong Kong. ${ }^{14}$ Public marches to 'oppose political kidnapping' 抗議政治綁架 took place in Hong Kong in January and again in June 2016, after Lam told his story to the press. Meanwhile, Gui Minhai remains detained in China; in October 2016, on the one-year anniversary of his detention, his daughter Angela Gui wrote a poignant essay, 'Who will remember my father, Gui Minhai?', in which she noted that the lively publishing industry represented by Gui has 'gone unusually quiet'. ${ }^{15}$

Territorial governance means that China and Hong Kong each have their own legal jurisdictions. For Chinese authorities to probe into what is in Hong Kong a legal publishing industry, they require the physical presence of the booksellers in the mainland, along with evidence of sales there. Eric Cheung, a legal scholar at the University of Hong Kong, explained how the territoriality question entangles the two legal jurisdictions. 'Here is the question: When one's actions in Hong Kong are perfectly legal according to Hong Kong laws but are illegal in the mainland and have an effect there, are they subject to the mainland law? And can one be arrested accordingly 
when going to the mainland?"16 Selling banned books falls under criminal law in the mainland. According to China's race-based interpretation of nationality, Hong Kong citizens with Chinese ancestry are also Chinese citizens. Yet under the Basic Law, while in Hong Kong, Hong Kong citizens are subject to mainland laws of diplomacy and national security but not its criminal code.

Publishing books for the market in Hong Kong may affect mainland China - but to conclude, then, that the Chinese criminal code applies in Hong Kong is a violation of the Basic Law and 'One Country, Two Systems'. The interpretive problem for the Party-state is the absence of separation of powers - legislative, executive, and judicial — in mainland China and the overriding authority of the Party's decisions in all governmental spheres. The Party can decide, for example, that a given action has affected national security. 'Any actions,' said Cheung, 'could have some so-called "effect" in the mainland: something that you say, some articles that you write, or some demonstrations and rallies that you join ... Who will ever be "safe" and "innocent"?"17

The governing system of the SAR - a place of information and press freedoms - makes Hong Kong an important site for the national circulation of information and publications in China. The Hong Kong difference can constitute an opportunity in mainland China where political factions may exploit Hong Kong's freedom of information by leaking information about rivals to Hong Kong publishers. Extension of mainland politics to Hong Kong, especially factional politics, would explain increased central government interest in the SAR.

During 2016, book sales in Hong Kong declined, which also affected the major book dealers. By November 2016, more than half the bookshops at Hong Kong International Airport had closed down. These included six outlets of the Singapore-based Page One bookshops. Page One, a general interest bookstore, also closed their large shops in major malls, including Festival Walk in Kowloon Tong, Harbour City in Tsim Sha Tsui, and Times Square in Causeway Bay. ${ }^{18}$ The international Independent Publishers Association put the situation in stark terms: 'Publishers driving Hong Kong's 
once booming independent book business are living with the twin threats of financial ruin and arrest by Chinese mainland police in the wake of the Causeway Bay bookseller kidnappings'. ${ }^{19}$

This issue has also generated a round of negotiations resulting

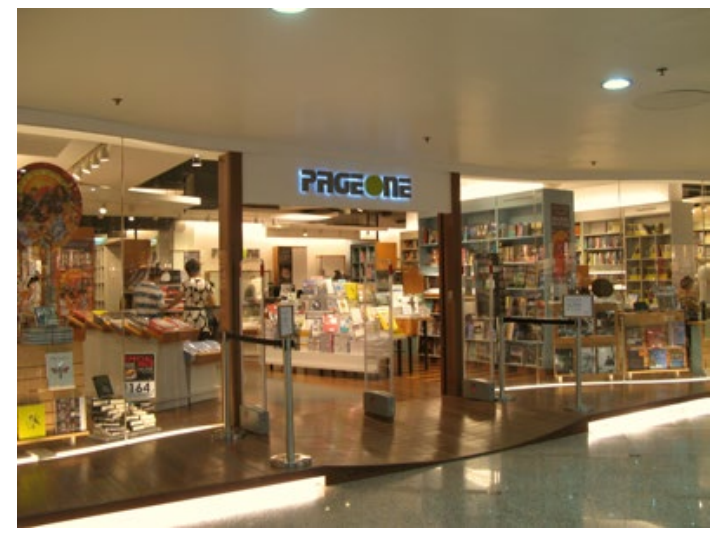

Page One bookshop Photo: Wikimedia Commons in further potential border effects. After Lam’s exposé, the Hong Kong government met with its counterparts in Beijing to 'overhaul the existing cross-border notification system’ between the Hong Kong Police Force and the Ministry of Public Security since it 'failed to keep Hong Kong informed' about the booksellers. ${ }^{20}$ The system has existed since 2001 but 'uncertainties exist because the process is not mandatory', which contributes to the problem of unreliable disclosure ${ }^{21}$ Meanwhile, Ningbo Public Security issued a statement that Lam had 'violated bail laws' and urged him to return. ${ }^{22}$ Then, a Shenzhen University academic said, 'extradition would be possible if a reciprocal judicial assistance agreement was struck between the two sides' ${ }^{23}$ Such an apparently banal comment is an example of how the circulation of ideas about governing Hong Kong enters public awareness for potential future negotiation. As Hong Kong Secretary for Security, Lai Tung-kwok 黎棟國, underscored, 'there is no legal arrangement for the transfer of a person to the mainland authorities and the Hong Kong government will handle all cases in accordance with the law of Hong Kong, ${ }^{24}$ The absence of an extradition agreement between the government of the Hong Kong SAR and the mainland makes it illegal for any police authority to transfer a person to mainland officials. 


\section{Governing Population Mobility}

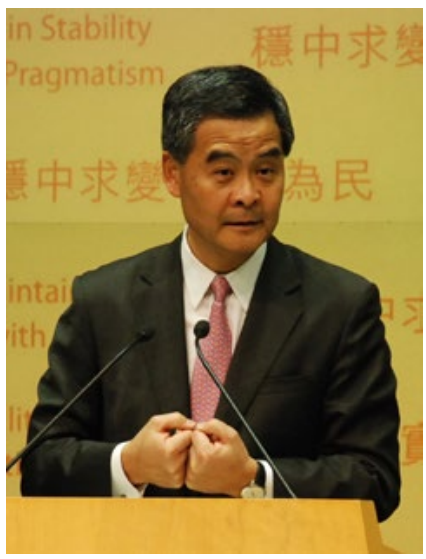

Leung Cheung-ying

Image: Wikimedia Commons
On 30 November 2016, the People's Repulbic's Hong Kong and Macau Affairs Office announced that the central government was lifting the ban on travel by pan-democrats to the mainland: they could once again apply for 'home return permits', which are required for Chinese Hong Kong identity card holders. The travel ban had applied to a number of prominent pro-democracy figures in Hong Kong, including some who had been in Beijing supporting the student-led protest in June 1989 and who had called for an end to one-party

rule. Viewed as a strategic olive branch to the pan-democrats, widespread speculation greeted the announcement. A Hong Kong representative to the National People’s Congress, Rita Fan Hsu Lai-tai 范徐麗泰, revealed it was the central government's decision, and that Hong Kong Chief Executive, Leung Cheung-ying 梁振英, had played no role in it, thus underscoring central government authority and sidelining Hong Kong's unpopular chief executive. ${ }^{25}$ Historically, Guangdong province, bordering Hong Kong, was the issuing authority of the home return permit, but in 2013 it changed from Guangdong provincial government to the central Ministry of Public Security 公安部.

Rescinding the nearly thirty-year-old ban on pan-democrats' travel to the mainland demonstrates strategic interest in governing political parties in Hong Kong. Today, these belong to one of three general groups: pro-Beijing, pan-democrats, and 'localists'. The platform of the pan-democratic parties promotes democracy within the framework of 'One Country, Two Systems'. Localists are relatively new political parties formed in 
2015-2016, some of which support independence for Hong Kong. A survey on Hong Kong's future, conducted by the Chinese University of Hong Kong in July 2016, showed that thirty-nine percent of young adults (aged fifteen to twenty-four) would prefer Hong Kong to become independent in 2047, when the current arrangement expires, rather than a regular subnational territory of the People's Republic of China, as specified by the 'One Country, Two Systems' arrangement. ${ }^{26}$

The idea of Hong Kong independence is unacceptable to China. In response, pro-government interests have begun to strategically govern the political parties with a view to working more pragmatically with the pan-democrats while isolating the recently formed pro-independence parties. For example, the Hong Kong Electoral Affairs Commission 选举管理 委员会 banned six localist candidates from standing in the 16 September 2016 Legislative Council election on the basis of their refusal to sign a new 'confirmation form' recognising three particular articles in the Basic Law that identify Hong Kong as 'an inalienable part of the People's Republic of China' and 'a local administrative region of the People's Republic of China' ${ }^{27}$ Then the banned activists organised what they called Hong Kong's 'first pro-independence rally' on 5 August, drawing 12,000 people. ${ }^{28}$ Results of the September election resulted in three localists elected to LegCo seats. But two were soon disqualified, in November 2016, after altering the oath of office. Rumours circulated that they were 'funded by pro-Beijing groups because no one had seen them take part in the Umbrella Movement'. ${ }^{29}$ Regina Ip said the decision, promoted by Beijing and issued by the Hong Kong High Court, had 'made clear to Hong Kong people the importance of territorial integrity and respect for the sovereignty of our country'.30

Coming after a year of uncertainty over the Hong Kong booksellers, combined with controversy over the co-location of PRC immigration security at West Kowloon, the decision to allow pan-democrats to travel to the mainland appeared as a measure of strategic governance that would make some good news out of border crossing. 


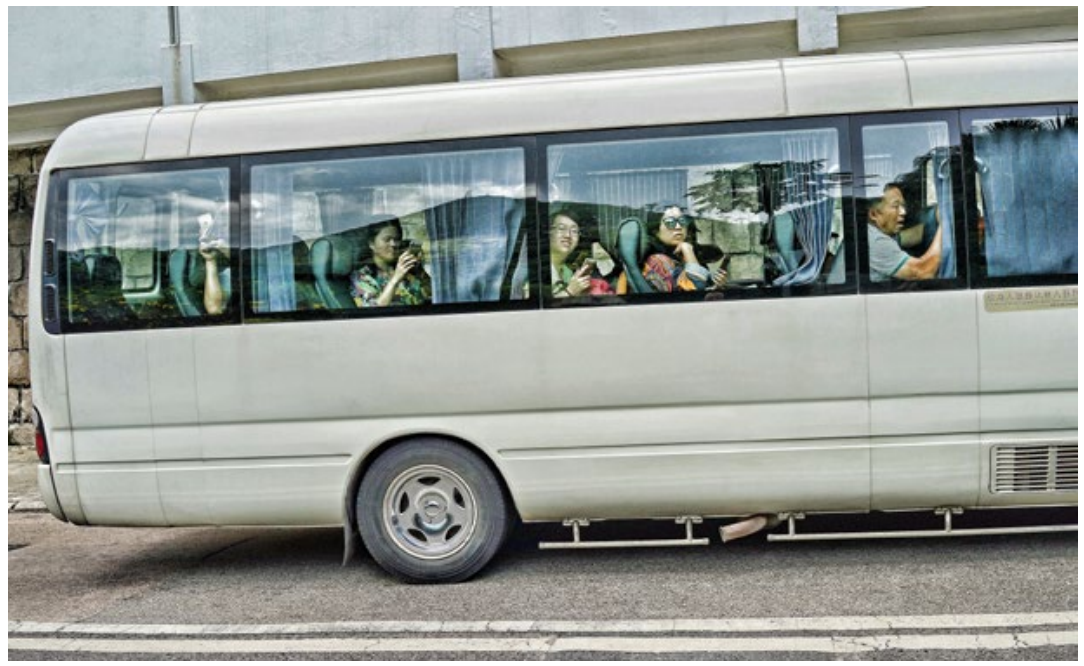

A busload of Chinese mainland tourists in Hong Kong Photo: Jamie Lloyd, Flickr

\section{Control Through Dynamic Governing}

State administration of governing functions normally takes place within relevant domestic jurisdictions. Administration of trans-border travel and trade, for example, takes place at customs and immigration checkpoints at national borders. But the Party-state also engages in more discrete forms of dynamic governance through incremental strategies that seek to extend control over people and places to achieve particular goals and outcomes. This kind of governance has nothing to do with legislation. As a 'unitary state' - that is, one without multiple parties or separation of powers China can choose to implement a range of targeted and sometimes surprising or idiosyncratic changes to established systems first, and then make discursive efforts to normalise them to the public later.

The Chinese state also advances sovereign authority in experimental ways, effectively treating subnational territories and territorial boundaries as dynamic or changing rather than as fixed places or established institutions. On the co-location issue, for example, pro-government inter- 
ests advocate an alteration to the Basic Law, if necessary, to allow for it. Regarding the booksellers, Hong Kong and Beijing officials negotiated a revised cross-border notification system. Rescinding the travel ban for pan-democrats, meanwhile, emerged in the context of calls for Hong Kong independence rather than as a consequence of political reform or restoration of normal travel rights. From a governmentality perspective, such dynamic governing seeks to strategically advance authority over contested issues and, in the process, gain the cooperation of local government through negotiations while incrementally extending control. Hong Kong people's reactions help to reveal where they may have crossed a line. 
This text is taken from China Story Yearbook 2016: Control, edited by Jane Golley, Linda Jaivin and Luigi Tomba, published 2017 by ANU Press, The Australian National University, Canberra, Australia. 